\title{
Carbon brainprint - an estimate of the intellectual contribution of research institutions to reducing greenhouse gas emissions
}

\section{Article}

Accepted Version

Creative Commons: Attribution-Noncommercial-No Derivative Works 4.0

Chatterton, J., Parsons, D., Nicholls, J., Longhurst, P., Bernon, M., Palmer, A., Brennan, F., Kolios, A., Wilson, I., Ishiyama, E., Clements-Croome, D., Elmualim, A., Darby, H., Yearley, T. and Davies, G. (2015) Carbon brainprint - an estimate of the intellectual contribution of research institutions to reducing greenhouse gas emissions. Process Safety and Environmental Protection, 96. pp. 74-81. ISSN 0957-5820 doi: https://doi.org/10.1016/j.psep.2015.04.008 Available at https://centaur.reading.ac.uk/67747/

It is advisable to refer to the publisher's version if you intend to cite from the work. See Guidance on citing.

Published version at: http://dx.doi.org/10.1016/j.psep.2015.04.008

To link to this article DOI: http://dx.doi.org/10.1016/j.psep.2015.04.008

Publisher: Elsevier

All outputs in CentAUR are protected by Intellectual Property Rights law, including copyright law. Copyright and IPR is retained by the creators or other copyright holders. Terms and conditions for use of this material are defined in 
the End User Agreement.

www.reading.ac.uk/centaur

\section{CentAUR}

Central Archive at the University of Reading

Reading's research outputs online 
Process Safety and Environmental Protection, Volume 96, July 2015, Pages 74-81

1 Carbon Brainprint - an estimate of the intellectual contribution of research

\section{2 institutions to reducing greenhouse gas emissions}

3 Julia Chatterton ${ }^{\mathrm{a}}$, David Parsons ${ }^{\mathrm{a} *}$, John Nicholls ${ }^{\mathrm{a}}$, Phil Longhurst ${ }^{\mathrm{a}}$, Mike Bernon ${ }^{\mathrm{a}}$, Andrew

4 Palmer $^{\mathrm{a}}$, Feargal Brennan ${ }^{\mathrm{a}}$, Athanasios Kolios ${ }^{\mathrm{a}}$, Ian Wilson ${ }^{\mathrm{b}}$, Edward Ishiyama ${ }^{\mathrm{c}}$, Derek

5 Clements-Croome ${ }^{\mathrm{d}}$, Abbas Elmualim ${ }^{\mathrm{d}}$, Howard Darby ${ }^{\mathrm{e}}$, Thomas Yearley ${ }^{\mathrm{f}}$, Gareth Davies ${ }^{\mathrm{g}}$

$6 \quad{ }^{a}$ Cranfield University, Cranfield, Bedford, MK43 0AL, UK (j.chatterton@cranfield.ac.uk,

7 d.parsons@cranfield.ac.uk, J.R.Nicholls@cranfield.ac.uk, P.J.Longhurst@cranfield.ac.uk,

8 m.p.bernon@cranfield.ac.uk, a.palmer@Cranfield.ac.uk, f.brennan@cranfield.ac.uk,

9 a.kolios@cranfield.ac.uk)

$10{ }^{b}$ Department of Chemical Engineering and Biotechnology, University of Cambridge, New

11 Museums Site, Cambridge CB2 3RA, UK (diw11@cam.ac.uk)

$12{ }^{\mathrm{c}}$ Downstream Research, IHS, 133 Houndsditch, London, EC3A 7AH

13 (ishiyama.edward@googlemail.com) Formerly at University of Cambridge

$14{ }^{\mathrm{d}}$ School of Construction Management and Engineering, University of Reading, PO Box 220,

15 Reading, RG6 6AY, UK (d.j.clements-croome@reading.ac.uk, a.a.elmualim@reading.ac.uk)

$16{ }^{\mathrm{e}}$ Technologies for Sustainable Built Environments Centre, University of Reading, PO Box

17 220, Reading, RG6 6AY, UK (HDarby@peterbrett.com)

$18 \mathrm{f}$ Estates and Facilities, University of Reading, PO Box 220, Reading, RG6 6AY, UK

19 (t.yearley@reading.ac.uk)

Published by Elsevier. This is the Author Accepted M anuscript issued with:

Creative Commons Attribution Non-Commercial No Derivatives License (CC:BY:NC:ND 3.0). 
21 Icon Print Innovations P/L, Wentworthvill, NSW, Australia (gareth@icon2100.com)

22 (Formerly at Newera Controls Solutions Limited).

23 * Corresponding author. Tel: +44 1234 750111; Fax: +44 1234 752971. E-mail address:

24 d.parsons@cranfield.ac.uk (D. J. Parsons) 
26 Carbon Brainprint - an estimate of the intellectual contribution of research

27 institutions to reducing greenhouse gas emissions

\section{Abstract}

30 Research and innovation have considerable, currently unquantified potential to reduce

31 greenhouse gas emissions by, for example, increasing energy efficiency. Furthermore, the

32 process of knowledge transfer in itself can have a significant impact on reducing emissions,

33 by promoting awareness and behavioural change. The concept of the 'carbon brainprint' was

34 proposed to convey the intellectual contribution of higher education institutions to the

35 reduction of greenhouse gas emissions by other parties through research and teaching/training

36 activities. This paper describes an investigation of the feasibility of quantifying the carbon

37 brainprint, through six case studies. The potential brainprint of higher education institutes is

38 shown to be significant: up to $500 \mathrm{kt} \mathrm{CO}_{2} \mathrm{e} /$ year for one project. The most difficult aspect is

39 attributing the brainprint among multiple participants in joint projects.

41 Keywords: carbon brainprint, carbon footprint, universities, research, higher education,

42 greenhouse gas. 


\section{Introduction}

45 The need to reduce greenhouse gas (GHG) emissions is widely, though not universally, 46 accepted. In the Climate Change Act 2008, the UK Government committed the country to

47 reducing its GHG emissions by $34 \%$ by 2020 and $80 \%$ by 2050 . These targets require action to reduce GHG emissions from all sections of the economy, including universities, which are expected to cut their own carbon footprints in line with these national targets (HEFCE, 2010).

50 These emissions vary widely with the size and nature of the institutions: annual GHG emissions by universities from fuel and energy consumption in 2005 were $1-$ $90 \mathrm{kt} \mathrm{CO}_{2} \mathrm{e} /$ institution (SQW, 2010). This concern is part of a wider trend for universities, like other business, to study and improve their environmental performance (Baboulet and Lenzen, 2010).

The process of quantifying their own emissions has led universities to consider the possibility of measuring the contribution of research to reducing the emissions of other organisations. Universities could have an impact through research leading to new technologies, the transfer of the results of past research into practice, developing novel ways to promote behavioural change, and training and education to provide the necessary knowledge and skills to effect change. The carbon footprint is a commonly-used measure of the total set of GHG emissions

61 caused directly and indirectly by an individual, organisation, event or product, although the

62 definition and the boundaries used vary between studies according to their context and 63 purpose (Pandey et al., 2011). The phrase 'carbon brainprint' was first proposed as an analogue of the carbon footprint to describe the wider impact of universities on GHG emissions emissions by the Deputy Chief Executive of the Higher Education Funding Council for England (HEFCE) during consultation on its GHG emissions reduction targets. 
67 The objectives of the Carbon Brainprint project were to test whether it was possible to

68 quantify the carbon brainprints of university activities, explore the difficulties in doing so,

69 propose procedures and estimate the potential brainprints of several examples. This paper

70 will summarise the general approach, briefly describe the case studies used to develop the

71 concept, discuss what was learned from the case studies and identify some of the remaining

72 problems in developing a general method for all types of university activities.

$74 \quad 2$ Methods

\subsection{Case-study approach}

76 As the objectives required development and testing of a method to quantify a previously

77 conceptual measure, a multiple case study approach was adopted, in which the method evolved during the case studies. This approach was selected in preference to defining a method in advance, so that it could respond to the insights gained and test the underlying concept not the implementation.

81 The case studies were selected in advance to provide a diverse set of examples, encompassing

82 technological interventions, training courses, detailed modelling and influencing behaviour

83 (Table 1). All the cases were expected to have some impact on carbon footprint reduction, but

84 only one (training for landfill gas inspectors) had quantified it. In addition to the technical

85 differences between the cases, the type of engagement of the universities with the users

86 varied, including implementation within the university campuses, long term research and

87 development contracts with single customers, 'pure' research that had yet to be put into

88 practice, and public sector consultancy relying on uptake by commerce to implement it. Each case was expected to provide different challenges to the methods being developed. 
90 After completion, the case studies were reviewed individually and collectively to assess the

91 need for revisions to the methods, areas of difficulty and conclusions related to the overall

92 aims.

93 Table 1. Initial case studies

\begin{tabular}{ll}
\hline Project & University \\
\hline Ceramic coatings for jet engine turbine blades to improve engine efficiency & Cranfield \\
Improved delivery vehicle logistics to save fuel & Cranfield \\
Training for landfill gas inspectors to improve methane capture & Cranfield \\
Novel offshore vertical axis wind turbines compared to conventional turbines & Cranfield \\
Intelligent buildings for energy management & Reading \\
Optimising defouling of oil-refinery preheat trains to reduce fuel consumption & Cambridge \\
\hline
\end{tabular}

94

\subsection{Guidelines}

A set of initial principles or guidelines for the case studies was drawn up by members of the project team, guided by the project steering committee and revised following the case studies. These principles were based on established approaches to carbon footprinting, including PAS 2050:2008 (BSI, 2008) and the Carbon Trust good practice guide (Carbon Trust, 2009),

100 which are underpinned by guidance from the Intergovernmental Panel on Climate Change

101 (Eggleston et al., 2006) and the methods of life cycle assessment (LCA) (e.g. Pennington et al., 2004; Rebitzer et al., 2004). However, as the intention was to obtain an estimate of a change in total emissions, it was anticipated that the level of detail would be coarser than that needed for an LCA of a specific functional unit, and that parts of the footprint unaffected by the change could be neglected. Indeed, it has been noted that, while footprints generally should be based on LCA, they have different characteristics, because they "have a primary

107 orientation toward non-LCA experts and society in general", whereas LCA is designed for

108 technical experts using indicators that "are not necessarily the lens through which society

109 views environmental protection" (Ridoutt et al., 2015). 
110 The guidelines divided the process of conducting a study into five main stages: system

111 definition, boundary definition, data gathering, assessment and uncertainty analysis.

112 System definition should begin with an interview with the main academics who carried out

113 the work, from which a general qualitative summary would be written describing the case, its

114 application and expected impact. The boundary definition should follow from this, specify ing

115 the process, spatial, temporal and conceptual boundaries of the system being considered. It

116 was anticipated that the boundaries would need to be drawn widely: in principle they would

117 include all upstream and downstream emissions over a long time period. As the estimate was

118 likely to contain significant uncertainty, a cut-off precision of $1 \%$ was suggested to avoid

119 spurious precision.

120 Data gathering should include both the activity and emissions. The activity data would

121 necessarily be specific to each case. Some emissions data would also be case-specific, but

122 much could be found in standard sources such as the European Life Cycle Database (ELCD,

123 2010) and the UK guidelines (AEA, 2010).

124 The assessment of the change in emissions was the core of the methods being developed. As the aim was to assess the change in emissions, it could be achieved by several approaches

126 depending on the data available, including directly evaluating baseline and changed

127 emissions, evaluating baseline emissions and applying a proportional change to a component

128 of the activity, or evaluating the change alone. The units to be used were mass of carbon

129 dioxide equivalent, using the global warming potential (GWP) with a 100 year time horizon

130 (GWP100). Depending on the context it might be appropriate to give a lifetime total, and

131 annual quantity, or both. For an intervention or development in the past, data about its uptake

132 or rate of use should enable assessment of its impact to date, referred to as the 'retrospective

133 brainprint' with reasonable confidence. More recent developments would rely for their 
134 impact on future uptake, implying much greater degree of uncertainty in their potential

135 results, known as the 'prospective brainprint'.

136 Uncertainty analysis is required as part of national GHG inventories (Eggleston et al., 2006),

137 and the carbon brainprint contained additional sources of uncertainty, particularly in the

138 prospective brainprint, so the same approach should be followed as far as possible. The usual

139 method is to define distributions for the main variables and parameters from data or expert

140 judgement, then use Monte Carlo simulation to derive output distributions and present the

141 results as the mean and 95\% confidence interval.

142 One issue that was identified in the guidelines, but not fully resolved, was the attribution of

143 the brainprint between multiple participants. When there were multiple university

144 participants, it was proposed that this could be based on the share of the research income, or

145 their documented roles. Indeed, if the aim was to estimate the impact of the university sector,

146 there would be no need for finer attribution. Dealing with other participants whose roles went

147 beyond implementation and uptake was anticipated to raise further difficulties.

\section{Case studies}

150 The case studies will be summarised, with emphasis on their contribution to the development

151 of the method. Full details can be found in the project report (Parsons et al., 2011).

\subsection{Ceramic coatings for jet engine turbine blades}

153 The aviation industry is estimated to contribute about $2-2.5 \%$ of GHG emissions, and the

154 number of aircraft in service is projected to double between 2011 and 2031 (Grote et al., 2014). Reducing emissions from aircraft through both operational changes and improvements 
156 in efficiency is, therefore, an important part of overall GHG emissions reduction. The Surface

157 Science and Engineering Group at Cranfield University has been working with Rolls-Royce

158 plc for over 17 years to improve the insulating performance of ceramic thermal barrier

159 coatings (TBCs), which are applied to jet turbine blades to protect them from the high

160 temperature gases leaving the combustion chamber and to increase the efficiency of the

161 engine. As a result, the TBCs used in the current generation of aircraft turbofan jet engines

162 permit operation at a temperature drop about $80^{\circ} \mathrm{C}$ greater than prior to the research, with an

163 estimated fuel saving of about $1 \%$ (inferred indirectly from other information). This case

164 study considered two engine types: the Trent 700, used on about half of the Airbus A330

165 aircraft currently in service, and the Trent 500, used on all Airbus A340-500 and A340-600

166 aircraft.

167 Good data on the numbers of aircraft delivered and in service was available from (Airfleets,

168 2011) and full data on existing orders came from (Airbus, 2010). The activity data was

169 statistical summaries of the number and distance of flight legs derived from the Association

170 of European Airlines (AEA) via another university project (C. Miyoshi, personal

171 communication). In the absence of other data, these were assumed to be typical of all

172 operators.

173 No fuel consumption data was available from the operators, so it was modelled using publicly available estimates (EMEP/EEA, 2009) for the cruise phase standard engine tests for take-off and landing (CAA, 2010). The emissions during extraction and refining of the fuel were taken from (ELCD, 2010). Estimates of the emissions associated with fuel transport and

177 manufacture of the blades showed they were negligible in comparison with the direct

178 emissions. 
179 The estimates of the current emissions reductions for individual aircraft were 1016-

$1801646 \mathrm{t} \mathrm{CO}_{2} \mathrm{e} / \mathrm{year}$ depending on the model, giving a total retrospective GHG emissions

181 reduction of $568 \mathrm{kt} \mathrm{CO}_{2} \mathrm{e} /$ year $(95 \%$ : 429-721) for the aircraft in service. Including all the

182 aircraft on order, the mean prospective GHG emissions reduction was $833 \mathrm{kt} \mathrm{CO} 2 \mathrm{e} / \mathrm{year}$

183 (95\%: 629-1060). Assuming a service life of 20 years, the total brainprint was approximately

$18416 \mathrm{Mt} \mathrm{CO}_{2} \mathrm{e}(95 \%$ : 12-20). More recent developments by the same team are included in

185 newer engine models and aircraft, so these totals are substantial under-estimates.

186 This case study raised few conceptual challenges, because it concerned an incremental

187 development in a well-studied field. It exemplified the large absolute values (relative to the

188 other case studies) that could be obtained from small changes in energy-intensive processes.

189 There was a residual uncertainty over the estimate of the change in efficiency, which had to

190 be inferred in the absence of experimental data. The assessment required a relatively detailed,

191 process-based model, similar to an IPCC Tier 3 assessment (EMEP/EEA, 2009). Using

192 operational consumption data (Tier 2) would have simplified the study and reduced some of

193 the uncertainties. The research was the work of a single university team, so the full brainprint

194 was attributed to the university. This study raised the question of rebound effects, in which

195 increased efficiency led to lower fares, resulting in more air travel. As there was no way to

196 establish a causal link, and many other factors influence the use of air travel, this was

197 excluded from the assessment.

\subsection{Novel offshore vertical axis wind turbines}

199 Researchers within the School of Engineering at Cranfield University were part of a

200 consortium to develop further the concept of Novel Offshore Vertical Ax is (NOVA) wind

201 turbines. These turbines have greater potential power capacity than conventional horizontal

202 axis turbines (HAWTs) and have a lower rotation speed and a more accessible hub, which 
203 allows for reduced emissions from maintenance over the turbine life cycle. The design has 204 been optimised to a much higher power rating than current models of HAWT, so fewer 205 turbines would be required for the same theoretical power output. It is expected that GHG 206 emissions for an installation of NOVA turbines would be lower than for conventional

207 HAWTs with the same output.

208 This project was still in its development stages, so there were no NOVA turbines in 209 operation, and the brainprint was entirely prospective, based on the results of an LCA that 210 was conducted during the project. The mean estimated total reduction in GHG emissions over 211 a lifetime of 20 years was $102 \mathrm{kt} \mathrm{CO}_{2} \mathrm{e}$ for installation of $1 \mathrm{GW}$ rated power, from a baseline 212 for the HAWT installation of $520 \mathrm{kt} \mathrm{CO}_{2} \mathrm{e}$.

213 This case study raised several difficulties with purely prospective assessments. There were

214 large uncertainties in many variables, giving a 95\% confidence interval for the lifetime

215 (construction, operation and maintenance and decommissioning) reduction in GHG emissions 216 of $-111-315 \mathrm{kt} \mathrm{CO}_{2} \mathrm{e}$. The large uncertainty, including the possibility of an increase in 217 emissions, arises because this is the difference of two random variables that are treated as 218 independent. In practice, common features of the two types of installation mean that there is 219 likely to be a positive correlation, which would reduce the variance of the difference. It 220 should also be noted that the LCA used in this estimate considered a single type of HAWT, whereas an LCA of five types of HAWT found a range of 18-31 g CO2e/kWh generated (Raadal et al., 2014), which is an additional source of uncertainty. (Direct comparison of the two LCAs is difficult due to differing assumptions and choice of functional unit, but Raadal et al. appear to estimate much higher total emissions.) A fundamental uncertainty not included in this estimate was whether any installations would be built. Although there is value in estimating the potential environmental benefits of current research, it would be 
unwise to make strong claims on this basis until field trials could provide data to reduce the uncertainties and realistic projections of uptake were possible.

229 As the project had multiple participants, there was a need to consider attribution if the brainprint was to be divided among them. Based on the composition of the team and the division of the budget, Cranfield University's contribution was estimated to be one-third, or

$23234 \mathrm{kt} \mathrm{CO}_{2} \mathrm{e}$. This assumed that the brainprint was attributed entirely to the research

233 institutions. If some of the innovations were contributed by the commercial partners in the consortium, it can be argued that the total university share should be reduced.

\subsection{Improved delivery vehicle logistics}

A Cranfield University PhD graduate and visiting fellow (Dr Andrew Palmer), contributed to transport recommendations for the food distribution industry (Faber Maunsell, 2007; Fisher et al., 2010), which were taken up by the food and grocery industry body IGD in the Efficient Consumer Response (ECR) initiative and implemented with 40 leading UK brands (IGD, 2011a). IGD reported that this initiative had reduced vehicle use by approximately 163 million road miles $\left(2.6 \times 10^{8} \mathrm{~km}\right)$, or $80 \mathrm{Ml}$ of diesel fuel, in the UK over approximately

242 four years to the date of the report in early 2011. The target was 200 million road miles $243\left(3.2 \times 10^{8} \mathrm{~km}\right)$ by the end of 2011 (IGD, 2011b), by maintaining the reductions that had been achieved. Using an emission factor of $3.1787 \mathrm{~kg} \mathrm{CO}_{2} \mathrm{e} / 1$ including indirect emissions (AEA, 2010), saving $80 \mathrm{Ml}$ of fuel is equivalent to a GHG reduction of $250 \mathrm{kt} \mathrm{CO}_{2} \mathrm{e}$. Applying a standard emission factor to the reduction in distance travelled gave a similar result.

247 The main uncertainty in these estimates was the distance travelled, or fuel use. (Wiltshire et al., 2009) suggest using a coefficient of variation (COV) of $2 \%$ for distances and $10 \%$ for fuel use per $\mathrm{km}$. As the estimates provided were for the reduction in distance travelled, with 
additional uncertainties, a normal distribution with mean 250 and COV 15\% was used, giving a $95 \%$ confidence interval of $177-323 \mathrm{~kg} \mathrm{CO}_{2} \mathrm{e} / \mathrm{kg}$.

In the short term, the best estimate of the future reduction is the average for the period reported: $63 \mathrm{kt} \mathrm{CO}_{2} \mathrm{e} /$ year. In the longer term, other changes in transport practice are likely to be introduced, and fuel efficiency is expected to improve (McKinnon, 2009), which would reduce the change in emissions from these measures. Conversely, the success of ECR may lead to similar measure being adopted by other operators both within and outside grocery distribution as part of wider sustainability initiatives, especially as studies show that 'green logistics' is neutral (Pazirandeh and Jafari, 2013) or beneficial (Ramanathan et al., 2014) for operational and financial performance. This raised the question of whether indirect reductions of this type should be included. The steering committee agreed to follow the practice of the Carbon Trust and exclude indirect reductions.

This case study again highlighted the question of attribution, as the authors of the underpinning report, other than Dr Palmer, were from Faber Maunsell (a consultancy business) and Heriott Watt University. From discussions with Dr Palmer, he was a main contributor to two of the six recommendations and contributed to the other four. An estimate of $30 \%$ was therefore used for attribution to him. Although not an employee of Cranfield University, the majority of his contribution was based on his $\mathrm{PhD}$ or work at Cranfield, so an estimate of $75 \%$ was used. Combining these, the mean estimate of the retrospective brainprint attributable to Cranfield was $56 \mathrm{kt} \mathrm{CO}_{2} \mathrm{e}$, or $14 \mathrm{kt} \mathrm{CO}_{2} \mathrm{e} / \mathrm{year}$, with greater uncertainty than

270 the aggregate figure.

\subsection{Landfill gas inspector training}

272 This case study considered the impact of a training course, run by academics at Cranfield 
training was a technical course for landfill gas inspectors to improve the recovery of methane at existing landfill sites. Landfill gas is the largest source of methane emissions in the UK: of the estimated UK total methane emissions of $2330 \mathrm{kt}$ in $2008,966 \mathrm{kt}\left(24 \mathrm{Mt} / \mathrm{CO}_{2} \mathrm{e}\right)$ came

277 from landfill (NAEI, 2011). The course trained 12 EA officers, and drew on the knowledge of 278 a retired EA landfill gas expert in addition to Cranfield staff. At the end of the course, the 279 trainees split undertook 24 site visits, making recommendations for improved methane 280 recovery, such as surface capping, gas well installation or replacement and pipeline 281 maintenance or balancing. A second course was subsequently run for an additional 12 282 officers.

283 The EA assessed the results of the initial set of 24 site visits and estimated that the measures

284 taken had resulted in the collection of an additional $7,600 \mathrm{~m}^{3} / \mathrm{hr}$ of landfill gas. The EA

285 suggested using a conservative estimate of $40 \% \mathrm{v} / \mathrm{v}$ for the methane content, giving $28626.63 \times 10^{6} \mathrm{~m}^{3}$ methane/year. Assuming a methane density of $0.68 \mathrm{~kg} / \mathrm{m}^{3}$ at $15^{\circ} \mathrm{C}$ and standard 287 atmospheric pressure yielded $18.1 \mathrm{kt} /$ year of methane, equivalent to $453 \mathrm{kt} \mathrm{CO}_{2} \mathrm{e} /$ year using 288 the standard GWP of 25 . However, the methane collected would ultimately be burned, 289 emitting carbon dioxide, so the estimated net reduction in GHG emissions was $290403 \mathrm{kt} \mathrm{CO} 2 \mathrm{e} /$ year.

291 Achieving this reduction required the installation of additional equipment, mainly mediumdensity polyethylene (MDPE) piping. Combining data on the MDPE used in the largest of 293 nine sites in a separate best-practice study (Raventós Martín and Longhurst, 2011) with an 294 LCA for MDPE (Baldasano Recio et al., 2005), the total emissions for the piping were 295 calculated to be less than $1.5 \mathrm{kt} \mathrm{CO}_{2} \mathrm{e}$. This was less than $1 \%$ of the gas captured from each 296 site in one year, so no estimates of equipment life cycle emissions were included in the 
297 brainprint calculations. Indirect benefits that could be obtained by using the gas to displace 298 fossil fuels were excluded.

299 There was no data on the work of the first group of trainees after the initial set of visits, or on 300 the second group. The initial interventions would continue to reduce emissions, but the rate of 301 production of methane within the landfill might change over time, and the gas recovery on 302 subsequent sites might be lower due to the selection of the initial set. Assuming the gas yield 303 deceased by 10\%/year and that each group made a similar set of visits, but achieved only $30470 \%$ of the reduction obtained in the first year, the total reduction in GHG emissions in year 2

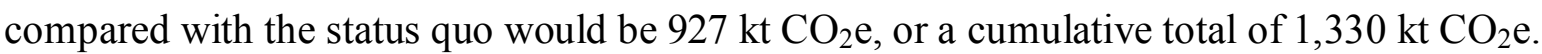

306 Extrapolating forward for an additional three years, assuming similar decreases in results, the 307 cumulative emissions reduction over five years would be 5,380 kt $\mathrm{CO}_{2} \mathrm{e}$.

308 In the uncertainty analysis, the change in emissions reported by the EA was treated as certain, 309 but, based on a survey of seven UK landfill sites (Allen et al., 1997), a uniform distribution in 310 the range $36-64 \% \mathrm{v} / \mathrm{v}$ was used for the methane concentration of the gas. This resulted in a $31195 \%$ confidence interval for emissions reduction in the first year of $370-638 \mathrm{kt} \mathrm{CO}_{2} \mathrm{e}$. All of

312 the other variables - the numbers of future visits, their effectiveness and the resulting changes 313 in emissions - were assumptions without supporting data, so were treated as highly uncertain 314 and given independent normal distributions with coefficients of variation of $50 \%$. The 315 resulting $95 \%$ confidence intervals were $1,090-1,570 \mathrm{kt} \mathrm{CO}_{2} \mathrm{e}$ for the first two years and $316 \quad 3,700-7,310 \mathrm{kt} \mathrm{CO}_{2}$ e for the five-year total.

317 The fact that the EA had audited the results of the first training cohort enabled a 318 straightforward and reliable estimate to be made of the total brainprint of this activity. It 319 highlighted the impact that interventions affecting methane could have, due to its high global 320 warming potential. Beyond the first year, the extrapolation entailed large uncertainties. The 
321 other main difficulty with this case study was attribution. The course was managed by

322 Cranfield University and taught by its staff, but included knowledge experience from EA

323 staff. The steering committee took the view that the course would not have taken place

324 without the involvement of a university or similar institution, so the brainprint could be

325 attributed solely to the university. However, there is also a case for dividing it between the

326 university and the EA.

\section{$327 \quad 3.5 \quad$ Intelligent buildings}

328 Over the past 20 years many different buildings have been labelled as "intelligent"

329 (Clements-Croome, 2004). Industry has many established intelligent building solutions but

330 finds it difficult to demonstrate and prove their benefits. The ideal system links the building,

331 systems within it and the occupants so they have some degree of personal control. Intelligent

332 controls help to match demand patterns (Noy et al., 2007; Qiao et al., 2006). It has been

333 demonstrated that effective action on GHG emissions requires building users to be involved

334 in both the process and the operation, so that they feel part of carbon management plans

335 (Elmualim et al., 2010).

336 A team consisting of researchers at the University of Reading, the University's Facilities

337 Management Directorate, Newera Controls Ltd. and Carnego Systems Ltd. conducted two

338 separate investigations to measure and demonstrate the potential for two important and

339 complementary approaches for achieving energy efficiency and GHG emission reductions in

340 buildings. This study was unique within the project in involving new research rather than

341 analysis of the results of previous projects.

342 The first investigation focused on saving electricity used for lighting, office equipment and

343 catering by influencing user behaviour in an office building on the main campus. Electricity

344 consumption was recorded over a 7 month period (October-April) in the trial, with each 
month divided into occupied days and unoccupied days. The results were compared with the same period in the previous year, having standardised both to an occupancy of 20.5 days/month. The reduction in emissions from electricity generation and distribution, using a conversion factor of $0.61707 \mathrm{~kg} \mathrm{CO}_{2} \mathrm{e} / \mathrm{kWh}$ (DECC, 2010), was $7.8 \mathrm{t} \mathrm{CO}_{2} \mathrm{e}$ from a baseline of $38.4 \mathrm{t} \mathrm{CO}_{2} \mathrm{e}$, a reduction of about $20 \%$. Although the uncertainty in the measured consumption was low, the comparison with the baseline introduced uncertainty due to the differences in occupancy, weather and other influences on behaviour.

The second investigation considered an interventionist approach in an accommodation block at the Henley Business School using intelligent monitoring and control systems. The existing Building Management Systems was enhanced using a Building Energy Management System to control some of the system parameters for occupied rooms and reduce the heating in unoccupied rooms. By comparing the results with another block before and during the trial, energy savings in the form of heating oil were estimated to be about $25 \%$. The reduction in emissions was estimated to be $3.3 \mathrm{~kg} \mathrm{CO}_{2} \mathrm{e} /$ day, but this was highly variable due to changes in occupancy and weather. The change would be much lower during the summer, but

360 additional savings could be made if the system was extended to other services, such as 361 lighting.

362 Given the uncertainty and variability present in both sets of data and the limited duration, the results were not extrapolated to a carbon brainprint for a whole year or a longer period. On the evidence of these two investigations, measures of this type could reduce non-domestic energy consumption by of the order of $20-25 \%$. A detailed carbon footprint study of one UK university found that building energy use accounted for one-third of its total GHG emissions,

367 of which half were from electricity use in buildings owned by the university (Ozawa-Meida et al., 2013), so the potential reductions within university estates are significant. Many of the 
same measures could be applicable to other non-domestic buildings, which are responsible for $20 \%$ of the UK's GHG emissions (Choudhary, 2012), but the total impact would be highly dependent on uptake.

\subsection{Optimising heat exchanger cleaning to reduce fuel consumption in oil} refineries

Although the largest proportion of GHG emissions from the use of fossil fuels arises from their combustion, the direct and indirect emissions during refining can account for up to $14 \%$ of the life-cycle emissions for petrol/gasoline (Elgowainy et al., 2014). Heating the crude oil from ambient temperature to its bubble point $\left(360-380^{\circ} \mathrm{C}\right)$ prior to fractional distillation is the major energy consumer amongst all distillation processes in the chemical and petroleum industries (Humphrey et al., 1991). About 60-70\% of the heat (Panchal and Huang-Fu, 2000) is recovered from the hot product streams of the crude oil distillation unit in a series of heat exchangers, known as the preheat train, prior to entering the furnace. Without the preheat train, $2-3 \%$ of the crude oil throughput would be used for heating the furnace. To maintain their efficiency, the heat exchangers need to be cleaned periodically, during which the performance of the preheat train is reduced.

Research in the Department of Chemical Engineering and Biotechnology at the University of of the preheat train to optimise the cleaning schedule, subject to constraints on the temperature at several points (Ishiyama et al., 2010, 2009).

Two refineries for which the necessary data were available were considered in the study: a studies were conducted with and without optimised cleaning schedules to estimate the difference in fuel use for heating. The only emissions considered were those arising from 
393 direct combustion of oil products to heat the crude oil prior to distillation, calculated using a

394 stoichiometric method based on the fuel composition. The predicted changes were small

395 fractions of the total throughput of the refinery, so the resulting change in total output was

396 neglected.

397 The analyses simulated a three year period for the Repsol YPF case and two years for Esso

398 Fawley. Compared with current practice, systematic cleaning at the Repsol YPF refinery was

399 predicted to result in an average GHG emissions reduction of $1.0 \mathrm{kt} \mathrm{CO}_{2} \mathrm{e} /$ year. If the desalter

400 inlet temperature was constrained, the emissions reduction was $0.77 \mathrm{kt} \mathrm{CO}_{2} /$ year. For the

401 Esso Fawley refinery, the predicted average reduction in emissions with systematic cleaning

402 was $1.4 \mathrm{kt} \mathrm{CO}_{2} /$ year.

403 The differences between the two refineries studied in terms of throughput and configuration

404 show that it is not possible to extrapolate directly from these results to other installations,

405 however, from the results obtained, a realistic estimate of the likely GHG emissions reduction

406 for each refinery is of the order of $1 \mathrm{kt} \mathrm{CO}_{2} /$ year. There were no implementations in practice

407 that could demonstrate this, but the university was working with the company IHS-ESDU to

408 include the algorithm in a commercial software product.

409 The estimation in this case was simple, as the existing model included most of the necessary

410 calculations. Within the model, the furnace efficiency was the main source of uncertainty.

411 Both results assumed a furnace efficiency of $90 \%$; if the efficiency was lower, greater

412 reductions in emissions would be obtained. 


\section{Discussion}

415 The Carbon Brainprint project aimed to develop and make available robust methods to

416 calculate both retrospective and potential estimates of the contributions that universities make

417 to reducing GHG emissions. Six contrasting case studies were used to develop and test the

418 methods, and to provide an indication of the benefits that might be obtained. The magnitude

419 of the retrospective brainprints varied widely between case studies, from about

$42012 \mathrm{t} \mathrm{CO}_{2} \mathrm{e} /$ year to over $500 \mathrm{kt} \mathrm{CO}_{2} \mathrm{e} /$ year (Table 2). The large absolute values were often the

421 result of small changes in efficiency in processes with high emissions. Although larger

422 proportional reductions in emissions were found in other studies, these were pilot studies, so

423 the absolute values were small, though the future potential if they were adopted is very large.

424 It was clear from the landfill gas case study that interventions to reduce GHGs other than

425 carbon dioxide can have very large impacts due to the high GWP of the gases considered.

426 Case studies in which changes in emissions or activity had already been measured provided

427 the clearest demonstration of the benefits of innovation or knowledge transfer to GHG

428 emission reduction. These cases were also simplest and least uncertain to evaluate, as they

429 allowed a direct calculation. Where such results had not been recorded, even for an existing

430 innovation, such as turbine blade coatings, it was necessary to use a model-based (Tier 3)

431 approach, which was considerably more time-consuming and contained many sources of

432 uncertainty. Inevitably, extrapolation to future impacts required a model, however simple,

433 and introduced many new uncertainties. If universities wish to provide a clear demonstration

434 of the impact of their work, some engagement with the users after implementation to collect

435 operational data would greatly simplify the process and provide the most reliable evidence.

436 In most cases, the change in emissions during operation far outweighed emissions involved in

437 the application of the innovation. The exception was the NOVA turbine study, in which the 
bulk of expected emissions would occur during construction and installation. It therefore required a full LCA, but fortunately an existing LCA model was available.

440 The most contentious issue in several studies was attribution of the brainprint among

441 different parties. Although it was recognised that the development and implementation are

442 vital, the steering committee concluded that the brainprint attributed to the research or

443 training team should include the full reduction in emissions, as it provided the foundation for

444 all that followed. Where the research involved collaboration between several higher

445 education or research sector parties, simple methods, such as considering the proportions of

446 the research budget or documented project roles could be used. Indeed, to assess the overall

447 benefits of universities, it is not necessary to attribute the brainprints to individual

448 institutions, though the institutions might have their own interest in doing so. Furthermore, if

449 the contribution of the non-university parties was similar in nature to that of the universities

450 (e.g. the transport logistics case study), the same method could be applied. The most difficult

451 cases were where there was a distinct contribution from non- university participants that went

452 beyond providing funding or implementing the results of research, for example the training

453 for landfill gas inspectors. One point of view was that if the benefits could not have been

454 realised without the university (or an equivalent) then the full brainprint could be attributed to

455 the university, and the results shown reflect this. If the intention was to make a comparison

456 between different universities, this might be adequate. However, this view may fail to

457 recognise the intellectual contribution from other parties and overestimate the role of

458 universities in total. Further work is needed to develop a more rigorous method of attribution.

459 All of the case studies were initially proposed because they were expected to result in a

460 reduction in GHG emissions, which left open the question of whether other activities might

461 result in increases. In general, energy efficiency meets both business and environmental 
objectives, and public policy supports reductions in GHG emissions and improved sustainability in general, so these are well-funded areas of research. Nevertheless, it is possible that research and development with other objectives, or even in pursuit of these aims, could have side effects that increased GHG emissions. The same methods could be applied to quantify these. As with the GHG emissions reductions, only a few activities with large impacts are likely to be significant, so the scope of a complete review could be limited by identifying any projects likely to result in large increases in energy consumption or emissions of methane and other potent GHGs. to specific universities)

\begin{tabular}{|c|c|c|}
\hline Project & $\begin{array}{l}\text { Emissions } \\
\text { reduction, } \\
\text { kt } \mathrm{CO}_{2} \mathrm{e} / \mathrm{year}\end{array}$ & Period \\
\hline $\begin{array}{l}\text { Ceramic coatings for jet engine turbine blades to } \\
\text { improve engine efficiency }\end{array}$ & 570 & Retrospective \\
\hline Improved delivery vehicle logistics to save fuel & 63 & Retrospective \\
\hline $\begin{array}{l}\text { Training for landfill gas inspectors to improve } \\
\text { methane capture }\end{array}$ & 400 & Retrospective \\
\hline \multirow[t]{2}{*}{ Intelligent buildings for energy management } & $\ll 1$ & Retrospective \\
\hline & $\begin{array}{l}\text { Potential } 20 \% \\
\text { reduction in } \mathrm{CO}_{2} \mathrm{e}\end{array}$ & Prospective \\
\hline $\begin{array}{l}\text { Novel offshore vertical axis wind turbines compared } \\
\text { with conventional turbines }\end{array}$ & $\begin{array}{l}1.7 \text { for } 1 \mathrm{GW} \\
\text { installed }\end{array}$ & Prospective \\
\hline $\begin{array}{l}\text { Optimising defouling of oil-refinery preheat trains to } \\
\text { reduce fuel consumption }\end{array}$ & $\sim 1$ per refinery & Prospective \\
\hline
\end{tabular}

\section{Conclusions}

474 The results of the project met the original objectives by using case studies to develop

475 procedures, which could be applied more widely, to quantify the external benefits of some

476 university activities in reducing GHG emissions, termed the carbon brainprint. The estimated

477 emissions reductions already achieved from single projects were up to $570 \mathrm{kt} \mathrm{CO}_{2} \mathrm{e} / \mathrm{year}$. The 
478 six projects were selected for study because they were expected to produce reductions in

479 GHG emissions, so the large reductions seen in three cases are probably relatively rare

480 compared with the more modest results found in the others. Whilst the carbon brainprint

481 should not be used to offset an institution's carbon footprint (up to $90 \mathrm{kt} \mathrm{CO}_{2} \mathrm{e} /$ year), it

482 provides an additional method for universities to evaluate and demonstrate their wider

483 impact.

484 The main difficulty identified in the case studies was the method of attribution amongst

485 multiple parties, especially when some were from outside the university and research sector.

486 This still needs further development. The case studies only included research, consultancy

487 and training with fairly direct links to outcomes. The benefits of general educational activities

488 were not addressed and would be difficult to quantify.

489 The project highlights the significant contribution of universities to reducing the GHG

490 emissions of others, and should encourage further institutions to attempt to evaluate the

491 brainprints of other activities.

492

\section{Acknowledgements}

494 The Carbon Brainprint project was supported by the Higher Education Funding Council for

495 England (HEFCE) under its Leading Sustainable Development in Higher Education

496 programme, with support for case studies from Santander Universities. HEFCE, Research

497 Councils UK and the Carbon Trust were members of the steering committee, which provided

498 guidance, but did not direct the research. The Carbon Trust also advised on best practice in

499 carbon footprinting. 
500 We are grateful to the many university staff at Cranfield, Cambridge and Reading

501 Universities who shared their work with us so enthusiastically.

502 We also thank the external partners and clients for the projects on which these case studies

503 are based: Rolls-Royce plc, the ETI NOVA consortium, IGD, the Environment Agency,

504 Esso, Repsol YPF, Carnego Systems Ltd and Newera Controls Ltd.

505

5067 References

507 AEA, 2010. 2010 Guidelines to Defra / DECC's GHG Conversion Factors for Company Reporting. Version 1.2.1 FINAL, Updated: 06/10/2010. Produced by AEA for the Department of Energy and Climate Change (DECC) and and the Department for Environment, Food and Rural Affairs (Defra), London.

Airbus, 2010. Orders and Deliveries [WWW Document]. URL http://www.airbus.com/company/market/orders-deliveries/

513 Airfleets, 2011. Production list [WWW Document]. URL http://www.airfleets.net/

514 Allen, M.R., Braithwaite, A., Hills, C.C., 1997. Trace Organic Compounds in Landfill Gas at Seven U.K. Waste Disposal Sites. Environ. Sci. Technol. 31, 1054-1061. doi:10.1021/es9605634

Baboulet, O., Lenzen, M., 2010. Evaluating the environmental performance of a university. J. Clean. Prod. 18, 1134-1141. doi:10.1016/j.jclepro.2010.04.006

Baldasano Recio, J.M., Gonçalves Ageitos, M., Jiménez Guerrero, P., 2005. Estimate of energy consumption and $\mathrm{CO} 2$ emission associated with the production, use and final disposal of sheets made of PVC-P, MDPE and bituminous materials. Universtat Politècnica de Catalunya, Barcelona. 
523

524

525

526

527

528

529

530

531

532

533

534

535

536

537

538

539

540

541

542

543

544

545

BSI, 2008. PAS 2050:2008 Specification for the assessment of the life cycle greenhouse gas emissions of goods and services. British Standards Institution, London.

CAA, 2010. Civil Aviation Organisation web site [WWW Document]. URL http://www.caa.co.uk/default.aspx?catid=702\&pagetype $=68$

Carbon Trust, 2009. Code of good practice for product greenhouse gas emissions and reduction claims (CTC 745). The Carbon Trust, London.

Choudhary, R., 2012. Energy analysis of the non-domestic building stock of Greater London. Build. Environ. 51, 243-254. doi:10.1016/j.buildenv.2011.10.006

Clements-Croome, D.J., 2004. Intelligent Buildings: Design, Management \& Operation. Thomas Telford, London.

DECC, 2010. Guidlines to Defra/DECC's GHG Conversion Factors for Company Reporting. London.

Eggleston, S., Buendia, L., Kyoko, M., Ngara, T., Tanabe, K. (Eds.), 2006. 2006 IPCC Guidelines for National Greenhouse Gas Inventories. Institute for Global Environmental Strategies, Kanagawa, Japan.

ELCD, 2010. European Life Cycle Database, ELCD II core data sets [WWW Document]. URL http://lca.jrc.ec.europa.eu

Elgowainy, A., Han, J., Cai, H., Wang, M., Forman, G.S., DiVita, V.B., 2014. Energy Efficiency and Greenhouse Gas Emission Intensity of Petroleum Products at U.S. Refineries. Environ. Sci. Technol. 48, 7612-7624. doi:10.1021/es5010347

Elmualim, A., Shockley, D., Valle, R., Ludlow, G., Shah, S., 2010. Barriers and commitment of facilities management profession to the sustainability agenda. Build. Environ. 45, 58-64. doi:10.1016/j.buildenv.2009.05.002 
546 EMEP/EEA, 2009. EMEP/EEA air pollutant emission inventory guidebook - 2009. Technical guidance to prepare national emission inventories. EEA Technical report No 9. European Environment Agency.

Faber Maunsell, 2007. Reducing the external costs of the domestic transportation of food by the food industry. Department for Environment, Food and Rural Affairs.

Fisher, D., McKinnon, A., Palmer, A., 2010. Reducing the external costs of food distribution in the UK, in: Delivering Performance in Food Supply Chains. pp. 459-477.

Grote, M., Williams, I., Preston, J., 2014. Direct carbon dioxide emissions from civil aircraft. Atmos. Environ. 95, 214-224. doi:10.1016/j.atmosenv.2014.06.042

HEFCE, 2010. Carbon reduction target and strategy for higher education in England. HEFCE, Bristol.

Humphrey, J.L., Seibert, A.F., Koort, R.A., 1991. Separation Technologies Advances and Priorities, DOE/ID/12920-1. USDA, Washington, D.C.

IGD, 2011a. ECR UK - Sustainable Distribution [WWW Document]. URL http://www.igd.com/index.asp?id=1\&fid=5\&sid=43\&tid=59

IGD, 2011b. Sustainable distribution: miles better [WWW Document]. URL http://www.igd.com/index.asp?id=1\&fid=1\&sid=3\&tid=41\&folid=0\&cid=2002 cleaning in a crude oil preheat train subject to fouling: Incorporating desalter control.

Ishiyama, E.M., Paterson, W.R., Wilson, D.I., 2009. Platform for Techno-economic Analysis of Fouling Mitigation Options in Refinery Preheat Trains. Energy Fuels 23, $1323-$ transport sector. Prepared for the Commission for Integrated Transport. 
NAEI, 2011. National Airborne Emissions Inventory [WWW Document]. URL http://www.naei.org.uk/

Noy, P., Liu, K., Clements-Croome, D.J., Qiao, B., 2007. Design Issues in Personalising Intelligent Buildings, in: Proceedings of 2nd International Conference on Intelligent Environments, Athens, 5-6 July 2007. Institute of Engineering and Technology, pp. $143-149$.

Ozawa-Meida, L., Brockway, P., Letten, K., Davies, J., Fleming, P., 2013. Measuring carbon performance in a UK University through a consumption-based carbon footprint: De Montfort University case study. J. Clean. Prod., Sustainability management beyond corporate boundaries 56, 185-198. doi:10.1016/j.jclepro.2011.09.028

Panchal, C.B., Huang-Fu, E.P., 2000. Effects of mitigating fouling on the energy efficiency of crude-oil distillation. Heat Transf. Eng. 21, 3-9. doi:10.1080/014576300270843

Pandey, D., Agrawal, M., Pandey, J.S., 2011. Carbon footprint: current methods of estimation. Environ. Monit. Assess. 178, 135-60. doi:10.1007/s10661-010-1678-y

Parsons, D.J., Chatterton, J., Clements-Croome, D., Elmualim, A., Darby, H., Yearly, T., Davies, G., Wilson, I., Ishiyama, I., 2011. Carbon Brainprint. Final Report (Summary report, guidance document and six case studies) (Client report No. HEFCE project LSDHE43). Cranfield University, University of Reading and University of Cambridge.

Pazirandeh, A., Jafari, H., 2013. Making sense of green logistics. Int. J. Product. Perform. Manag. 62, 889-904. doi:10.1108/IJPPM-03-2013-0059

Pennington, D.W., Potting, J., Finnveden, G., Lindeijer, E., Jolliet, O., Rydberg, T., Rebitzer, G., 2004. Life cycle assessment Part 2: Current impact assessment practice. Environ. Int. 30, 721-739. doi:10.1016/j.envint.2003.12.009 
Qiao, B., Liu, K., Guy, C., 2006. A Multi-Agent System for Building Control, in: Proceedings of IEEE/WIC/ACM International Conference on IAT, 18-22 December 2006. IEEE Computer Society Washington, DC, Hong Kong, pp. 653-659.

Raadal, H.L., Vold, B.I., Myhr, A., Nygaard, T.A., 2014. GHG emissions and energy performance of offshore wind power. Renew. Energy 66, 314-324. doi:10.1016/j.renene.2013.11.075

Ramanathan, U., Bentley, Y., Pang, G., 2014. The role of collaboration in the UK green supply chains: an exploratory study of the perspectives of suppliers, logistics and retailers. J. Clean. Prod. 70, 231-241. doi:10.1016/j.jclepro.2014.02.026

Raventós Martín, C., Longhurst, P., 2011. Development of a cost benefit model for a landfill gas infrastructure development. AWE Int. March, 17-23.

Rebitzer, G., Ekvall, T., Frischknecht, R., Hunkeler, D., Norris, G., Rydberg, T., Schmidt, W.-P., Suh, S., Weidema, B.P., Pennington, D.W., 2004. Life cycle assessment: Part 1: Framework, goal and scope definition, inventory analysis, and applications. Environ. Int. 30, 701-720. doi:10.1016/j.envint.2003.11.005

Ridoutt, B., Fantke, P., Pfister, S., Bare, J., Boulay, A.-M., Cherubini, F., Frischknecht, R., Hauschild, M., Hellweg, S., Henderson, A., Jolliet, O., Levasseur, A., Margni, M., McKone, T., Michelsen, O., Milà i Canals, L., Page, G., Pant, R., Raugei, M., Sala, S., Saouter, E., Verones, F., Wiedmann, T., 2015. Making Sense of the Minefield of Footprint Indicators. Environ. Sci. Technol. doi:10.1021/acs.est.5b00163

SQW, 2010. Carbon baselines for individual Higher Education Institutions in England. HEFCE, Bristol.

Wiltshire, J., Wynn, S., Clarke, J., Chambers, B., Cottrill, B., Drakes, D., Gittins, J., Nicholson, C., Phillips, K., Thorman, R., Tiffin, D., Walker, O., Tucker, G., Thorn, R., Green, A., Fendler, A., Williams, A., Bellamy, P., Audsley, E., Chatterton, J., 

of a BSI method for assessing GHG emissions from food. Technical annex to the final report. Report to Defra, Project Reference Number: FO0404.

623 